\title{
ピロール系化学吸着単分子膜とポリピロール膜を利用した 樹脂基板上の銅めっき接着力向上に関する研究
}

\author{
大久保 雄司 ${ }^{* * *}$ ，大西 正悟*，小川 一文*
}

\begin{abstract}
Improvement in Adhesion of Copper Plating on Resin Substrate Using Chemically Adsorbed Monolayer Containing Pyrrolyl Group and Polypyrrole Film
\end{abstract}

Yuji OHKUBO****, Shogo ONISHI*, and Kazufumi OGAWA*

* 香川大学大学院工学研究科 (下 761-0396 香川県高松市林町 2217-20)

**有限会社かがわ学生ベンチャー（７ 761-0104＼cjkstart香川県高松市高松町 1723-10）

* Graduate School of Engineering, Kagawa University (2217-20 Hayashi-cho, Takamatsu-shi, Kagawa 761-0396)

**Kagawa Gakusei Venture Ltd. (1723-10 Takamatsu-cho, Takamatsu-shi, Kagawa 761-0104)

\begin{abstract}
概要 配線パターンの微細化にともない，樹脂の表面粗さを増加させることなく，樹脂基板とめっき被膜との接着力を向 上させる技術が求められている。本研究では，樹脂基板と銅めっき被膜との界面に，中間層としてピロール系化学吸着単分子 膜とポリピロール膜を導入し，樹脂基板と銅めっき被膜との接着力を向上することを目指した。処理したサンプルの断面を SEMで観察し，樹脂表面があれていないことを確認した。そして，接着力をピール強度試験で評価した。最大平均ピール強度 は $0.98 \mathrm{kN} / \mathrm{m}$ を示し, 中間層がない場合と比較すると, 約 5 倍となった。
\end{abstract}

\begin{abstract}
As wiring patterns have become miniaturized, a technique is required for increasing the adhesion strength between the copper-plated layer and the resin substrate, without roughening the substrate. In this study, a chemically adsorbed monolayer containing a pyrrolyl group and a polymerized polypyrrole film were introduced as an interlayer between the copper layer and the resin substrate to increase the adhesion strength. A cross-section of the treated sample was observed by scanning electron microscopy (SEM). It was confirmed that the treatment did not roughen the resin substrate. The adhesion strength was evaluated by a peel strength test. The best sample had a sufficient average adhesion strength of $0.98 \mathrm{kN} / \mathrm{m}$, which was five times that of the untreated sample.
\end{abstract}

Key Words: Adhesion, Copper Plating, Peel Strength, Chemically Adsorbed Monolayer, Pyrrolyl Group

\section{1. 緒 言}

近年，携帯電話やパーソナルコンピュータに代表される ようなエレクトロニクス製品の小型化, 高機能化, 高性能 化がさらに進んでいる。しかし，エレクトロニクス製品の 小型化を進めると，プリント配線板における銅配線も微細 化し樹脂基板との接着面積が減り, 樹脂基板との接着力が 低下してしまう。ところでプリント配線板の回路成形法に は, 銅張積層板を出発材料として不要な部分の銅箔をエッ チングで除去するサブトラクティブ法と, 樹脂基板（絶縁 基板）を出発材料としてその上に銅めっきを行って回路を 形成するアディティブ法がある。サブトラクティブ法に用 いる銅張積層板の場合は，銅箔に樹脂との接着力を高める 処理が施されている。一方, アディティブ法では, めっき 被膜との接着力を高めるために樹脂表面の処理が必要であ る。本報はアディティブ法によるプリント配線板の接着力 向上方法を対象とする。この接着力の良否は, 製品の信頼 性や歩留まりを左右するため, 非常に重要である1)。一般
的に，金属と有機ポリマーを接着することは容易ではなく， 耐剥離性の優れた金属被膜を得ることは難しい2)。これま で, 薬液によって樹脂基板の表面粗さを増加させる方法, あるいは凸凹層を樹脂基板上に形成した後，めっきを行う 方法など，種々報告されてはいるが，いずれもアンカー効 果を利用したものであり 3) 5)，樹脂表面だけでなく配線パ ターンの粗れを引き起こしてしまうので, ファインピッチ 化が困難である。したがって，樹脂の表面粗さを増加する ことなく，接着力を向上させる技術が期待されている。

われわれは, 以前, ピロール系化学吸着単分子膜とピ ロールを重合してポリピロール膜をガラス基板に固定し， このポリピロール膜によって，銅イオンを基板へ固定する

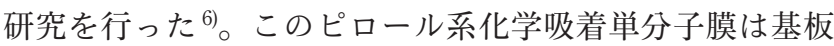
と共有結合し，その化学吸着単分子膜とポリピロール膜も 共有結合していた。そして，ピロール環内の窒素原子と銅 イオンが有機金属錯体を形成することにより，銅イオンが 固定された。そこで，この銅イオンの固定技術を，有機物 である樹脂基板と無機物である銅めっき被膜との接着力向 
上技術として応用できると考えた。

本報では，樹脂基板と銅めっき被膜間の接着力向上の新 しい方法について述べる。本研究では, 樹脂基板と銅めっ き被膜との中間層として, ピロール系化学吸着単分子膜と ポリピロール膜を導入し, 樹脂の表面粗さを大幅に増加さ せることなく，2つの材料間の接着力を向上させることを 目的とする。

\section{2. 方 法}

\section{1 薬剂 $\cdot$ 材料 $\cdot$ 使用器具}

分子の末端にピロリル基をもち，もう一方の末端にトリ クロロシリル基をもち，炭化水素鎖を接続基とした N-ピロ リルウンデシルトリクロロシラン $\left(\mathrm{C}_{4} \mathrm{H}_{4} \mathrm{~N}-\left(\mathrm{CH}_{2}\right)_{11}-\mathrm{SiCl}_{3}\right.$, 以 下 PUCS と略す。信越化学工業社製) は, 反応性の界面活 性剂であり, Fig. 1のように, 基板上の水酸基と脱塩化水 素反応し, 基板と共有結合する77。さらに, 基板上の微量 な水分之脱塩化水素反応し, 隣接する化学吸着剤どうしも 共有結合（シロキサン結合）する。このようにして, 基板 之強固に結合した単分子膜が形成される7)。本研究では, ピロリル基を有したPUCSで構成される化学吸着単分子 膜 (以下 PUCS 化学吸着単分子膜と略す。英語表記は PUCS-CAM とする。）を用いて, 接着性向上の検討を行っ た6),8 12)。PUCS 化学吸着液の溶媒として, 脱水クロロホル ム（和光純薬工業社製）を使用し, PUCS の溶解度を調整 するため, ジメチルシリコーン（KF-96L-1.5cs, 信越化学 工業社製）を添加した。脱水クロロホルムとジメチルシリ コーンの溶液中の水分を減らすため, モレキュラーシーブ (モレキュラーシーブ4A，ナカライテクス社製）を使用し た。ピロール溶液は, アセトニトリル (関東化学社製) に ピロール $\left(\mathrm{C}_{4} \mathrm{H}_{5} \mathrm{~N}\right.$, 関東化学社製 $)$ を添加することで調製 し, PUCS 化学吸着単分子膜上でポリピロール膜を成長さ せるために使用した。PUCS化学吸着単分子膜のピロリル 基とピロールを酸化重合するため, 酸化剂として, 塩化鉄 $\left(\mathrm{Fe}(\mathrm{III}) \mathrm{Cl}_{3}, \mathrm{MERCK} \& \mathrm{Co} .\right.$, Inc. 製) と塩化パラジウム $\left(\mathrm{Pd}(\mathrm{IV}) \mathrm{Cl}_{4}\right.$, 和光純薬工業社製) を使用した。サンプル基 板表面を洗浄するため, 洗浄液として, クロロホルム（和 光純薬工業社製), アセトン (和光純薬工業社製), エ夕 ノール (ソルミックスA-7, 日本アルコール販売社製) を 使用した。無電解銅めっきを行う前に, 表面を活性化する ため, 塩化すず水溶液（S-10X，上村工業社製）と塩化パ ラジウム水溶液 (A-10X, 上村工業社製)を使用した。ポ リピロール膜上で無電解銅めっきを行うために，無電解銅 めっきキット（Thru-Cup PEA Ver. 3, 上村工業社製）を使 用した。無電解銅めっき後に電気銅めっきを行うため, 硫 酸水溶液と硫酸銅水溶液 (アデカスーパーケミカル TFE2001，アデカ社製）を使用した。陽極板として，含リ ン銅 $(150 \times 50 \times 2 \mathrm{~mm}$, 山本鍍金試験器製）を使用した。

サンプル基板として，ポリフェニレンスルフィド(PPS) と

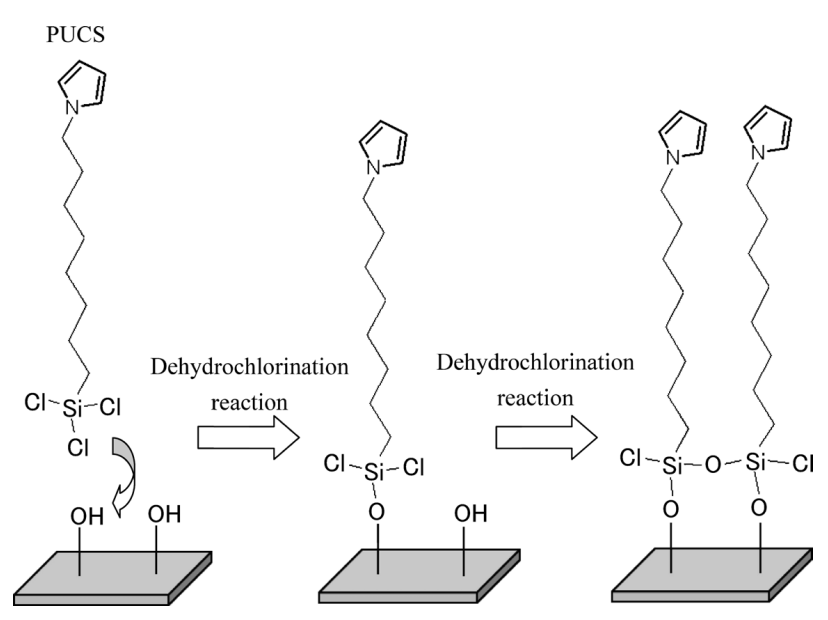

Fig. 1 Reaction of PUCS including chlorosilyl-groups with a substrate

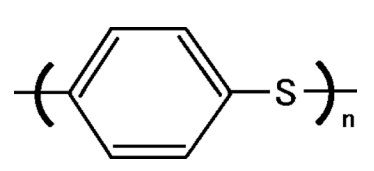

Fig. 2 Chemical formula of polyphenylene sulfide (PPS)

円柱状ガラスフィラー（直径 $10 \mu \mathrm{m}$, 長さ $100 \mu \mathrm{m}$ ）の体積 比率が 60 : 40 である樹脂基板（PPS基板， $50 \times 20 \times 2 \mathrm{~mm}$ ) を使用した (Fig. 2参照)。PPS基板を使用した理由は, $250^{\circ} \mathrm{C}$ 以上の耐熱性を有し, 耐薬品性にも優れており, 電 気製品における使用頻度が高く, 非常に実用性が高いため である。このPPS 基板は, アルプス電気社から提供された。 そして, スライドガラス $(\mathrm{s}-1111,76 \times 26 \times 1 \mathrm{~mm}$, 松浪ガ ラス社製）をリファレンスとして使用した。

比較実験に扔いて, 薬液を使って樹脂基板の表面粗さを 増加させるため, フッ酸緩衝液(BHF)を使用した。フッ酸 緩衝液(BHF)は，50\%のフッ化水素酸( $\mathrm{HF}), 40 \%$ のフッ化 アンモニウム水溶液 $\left(\mathrm{NH}_{4} \mathrm{~F}\right)$, 脱イオン水を $2: 5: 5$ の体積比 率で混合し, 調製した。

\section{2 実験手順}

Fig. 3 に，全実験工程の概念図を示す。そして，各工程 の詳細について, 以下に記載する。

\section{2 .1 前洗浄}

最初に，ビーカーへ有機溶媒を入れ，その中にサンプル 基板（PPS 基板）を浸漬した。つぎに，サンプル基板を入 れたビーカーを超音波バス（US-4R, AS ONE 社製) 内へ 置き, 超音波バスの洗浄浴内基準線まで水道水を入れた 後, 5 分間超音波洗浄を行った。超音波洗浄用の有機溶媒 として, クロロホルム, アセトン, エタノールを順番に使 用し，各有機溶媒に対して，それぞれ5 分間ずつ超音波洗 浄を行った。そして，3番目のエタノールの超音波洗浄後, サンプル基板をエタノールから引き上げ, 室温大気中で, エアガンを用いてドライエアを吹き付け, 乾燥させた。

つぎに，サンプル基板表面の水酸基の数を増やすために， 
プラズマ処理装置（RMD-150，アルバック製）を用いて， 有機洗浄後のサンプル基板に 60 秒間酸素プラズマ処理を 行った。このときの出力は, $600 \mathrm{~W}$ に設定した。

\subsubsection{PUCS 化学吸着単分子膜の作製}

PUCSのクロロシリル基は，水分との反応性が極めて高 く, 大気中で扱うと, PUCS どうしが重合してポリマーと なる。そこで, 湿度調整したグローブボックス内でPUCS 化学吸着単分子膜の製膜を行った ${ }^{6,77,13)}$ 。

グローブボックス内にドライエアを流し，湿度を $10 \%$ 以 下に調節した。グローブボックス内で, 褐色瓶の中に脱水 クロロホルムを入れ，つぎにPUCSを添加して溶解させ， $0.1 \mathrm{M}$ の PUCS 希釈液を調整した。そして, シャーレの中で 脱水クロロホルムとジメチルシリコーンを $33: 67$ の体積比 率で混合し， $0.1 \mathrm{M}$ の PUCS 希釈液を添加して， $5.0 \times 10^{-3} \mathrm{M}$ のPUCS 化学吸着液を調製した。

引き続きグローブボックス内で, 前述のように洗浄した サンプル基板を, $5.0 \times 10^{-3} \mathrm{M}$ の PUCS 化学吸着液に室温で 2 時間浸漬し反応させた。サンプル基板を PUCS 化学吸着 液から引き上げ, グローブボックス内で, クロロホルム,

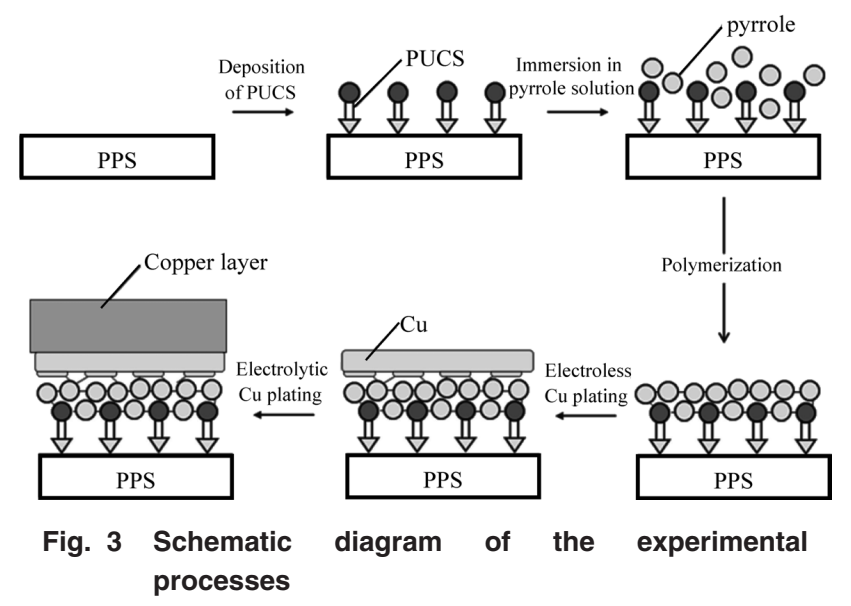

アセトンの順番で各5分間すすぎ洗いした。基板をグロー ブボックスから出した後, 前洗浄之同様に, クロロホルム, アセトン，エタノールの順番で各5 分間超音波洗浄した。3 番目のエタノールの超音波洗浄後, サンプル基板をエ夕 ノールから引き上げ, 室温大気中で, エアガンを用いてド ライエアを吹き付け，乾燥させた。

\subsection{3 ポリピロール膜の作製}

シャーレの中にアセトニトリルを入れ，次にピロールを

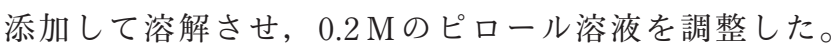

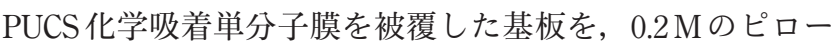
ル溶液に室温で 3 分間浸漬した。その後, 基板をピロール 溶液から引き上げ，自然乾燥させた。

つぎに， 3 種類の酸化剂溶液を調製した。1つ目の酸化剂 溶液として，アセトニトリルに塩化鉄を溶解させ，塩化鉄 酸化剂溶液を調製した。2つ目の酸化剂溶液として, 脱イ オン水に塩化パラジウムを溶解させ，塩化パラジウム酸化 剂溶液を調製した。3つ目の酸化剂溶液として，アセト二 トリルに塩化鉄を溶解させ，さらにピロールを添加し，ピ ロール塩化鉄酸化剂溶液を調製した。

上記の 3 種類の酸化剂溶液のいずれかに，ピロール溶液 から引き上げて自然乾燥した基板を $30^{\circ} \mathrm{C} て ゙ 5$ 分間浸漬し た。デジタルホットプレート（ND-1，AS ONE社製）を使 用して，液温の制御を行った。サンプル基板を酸化剂溶液 から引き上げ，脱イオン水で1分間すすぎ洗いした。Table 1 に，各サンプル処理工程の比較表を示す。これらの工程 により, PUCS 化学吸着単分子膜に結合したポリピロール 膜を作製した 6),14,15)。

\subsection{4 無電解銅めっき}

まず，表面を活性化するため，PUCS化学吸着単分子膜 とポリピロール膜で被覆したサンプル基板を塩化すず水溶 液 (S-10X) に常温で 3 分間浸漬し, 水洗後, 塩化パラジウム 水溶液 $(\mathrm{A}-10 \mathrm{X})$ に $30^{\circ} \mathrm{C} て ゙ 3$ 分間浸漬した。そして，無電解

Table 1. Comparative table of experimental procedures

\begin{tabular}{|c|c|c|c|c|c|c|c|}
\hline Process/Sample name & A & B & $\mathrm{C}$ & $\mathrm{D}$ & $\mathrm{E}$ & $\mathrm{F}$ & G \\
\hline Oxygen plasma treatment & $\bullet$ & $\bullet$ & $\bullet$ & $\bullet$ & $\bullet$ & $\bullet$ & $\bullet$ \\
\hline Deposition of PUCS (Preparation of PUCS-CAM) & & $\bullet$ & $\bullet$ & $\bullet$ & $\bullet$ & $\bullet$ & $\bullet$ \\
\hline Immersion in $\mathrm{FeCl}_{3}$ solution with pyrrole & & & $\bullet$ & & & & \\
\hline Immersion in pyrrole solution (first) & & & & $\bullet$ & $\bullet$ & $\bullet$ & $\bullet$ \\
\hline Immersion in $\mathrm{FeCl}_{3}$ solution (first) & & & & $\bullet$ & $\bullet$ & $\bullet$ & \\
\hline Immersion in $\mathrm{PdCl}_{4}$ solution (first) & & & & & & & $\bullet$ \\
\hline Immersion in pyrrole solution (second) & & & & & $\bullet$ & $\bullet$ & $\bullet$ \\
\hline Immersion in $\mathrm{FeCl}_{3}$ solution (second) & & & & & & $\bullet$ & \\
\hline Immersion in $\mathrm{PdCl}_{4}$ solution (second) & & & & & & & $\bullet$ \\
\hline Electroless Cu plating & $\bullet$ & $\bullet$ & $\bullet$ & $\bullet$ & $\bullet$ & $\bullet$ & $\bullet$ \\
\hline Electrolytic Cu plating & $\bullet$ & $\bullet$ & $\bullet$ & - & $\bullet$ & $\bullet$ & $\bullet$ \\
\hline
\end{tabular}


銅めっきキットを使用して, $30^{\circ} \mathrm{C} て ゙ 30$ 分間無電解銅めっ きを行った。デジタルホットプレート（ND-1, AS ONE 社 製）を使用して，液温の制御を行った。

\section{2 .5 電気銅めっき}

無電解銅めっきにより製膜した銅めっき被膜の膜厚は, ピール強度試験を行うには十分ではなかった。そこで，銅 めっき被膜の膜厚を増加するために, 電気銅めっきを行っ た。陽極側に含リン銅板, 陰極側にはPUCS 化学吸着単分 子膜とポリピロール膜で被覆後, 無電解銅めっきを行った サンプル基板を設置し, $10 \mathrm{wt} \%$ の硫酸水溶液に常温で 3 分 間浸漬した。つぎに, 硫酸銅水溶液へ浸漬し, 室温で 90 分 間通電した $\left(0.02 \mathrm{~A} / \mathrm{m}^{2}\right)$ 。そして, 水洗後, 室温大気中で, エアガンを用いてドライエアを吹き付け, 乾燥させた。 SEMにより, 銅めっき被膜の膜厚が約 $20 \mu \mathrm{m}$ であることを 確認した。

\section{3 評価方法}

2.3.1 水滴接触角測定 ${ }^{6), 13), 16)}$

サンプル基板の親水性, そして, PUCS 化学吸着単分子 膜とポリピロール膜の製膜状態を確認するため, 自動接触 角計（CA-VP150, 協和界面科学社製）を使用し, 水滴接 触角を測定した。

水滴接触角測定には, キャビネット型脱イオン水製造装 置（PRO-0100-002，オルガノ社製）で製造した脱イオン水 を用いた。すべての基板を十分に乾燥させてから接触角測 定を行った。液滴量を $3 \mu \mathrm{L}$ に設定して基板上に水滴を滴下 した後, 滴下した水滴の様子を CCD カメラで 0.1 秒後に撮 影した。そして, 撮影した水滴の写真に対して $\theta / 2$ 法を適 応し, 接触角を求めた。各サンプル基板に対して, 基板上 の異なる 7 点で測定を行い, 最大最少の值を除いた残り 5 点の平均值を水滴接触角の值とした。

2.3.2 断面観察 $(\mathrm{SEM})$

酸素プラズマ処理工程, PUCS 化学吸着単分子膜の製膜 工程, およびポリピロール膜の製膜工程により, サンプル 基板と銅めっき被膜との界面があれていないことを確認す るため, 走査型電子顕微鏡 (JSM-5500, 日本電子社製) を 使用して, 断面観察を行った。このときの加速電圧は, 5 $\mathrm{kV}$ に設定した。

\subsection{3 ピール強度試験 ${ }^{17)}$}

サンプル基板と銅めっき被膜との接着力を評価するため, ピール強度試験機（ストログラフV10- $\beta$, 東洋精機製作所 製）を使用して，ピール強度試験を行った。電気銅めっき 後のサンプル基板の中央部に，カッターナイフを用いて 5 $\mathrm{mm}$ 間隔の切れ目を 4 本いれた。つぎに，あらかじめ銅めっ き被膜をサンプル端から約 $10 \mathrm{~mm}$ 剥がし, 引張試験機の チャック部分に挟んだ。そして, 銅めっき被膜が垂直方向 に均一に剥離するようにして, 試験機を一定速度 $(50$ $\mathrm{mm} / \mathrm{min}$ ) で作動させた。銅めっき被膜を引っ張り始めた直 後は, 銅めっき被膜がたるんでおり荷重の值が安定しな
かったため, 測定開始直後から荷重の值が安定するまでの 領域を除き，測定長さを $25 \mathrm{~mm}$ 以上とした。測定した荷重 の平均值を求め, この荷重平均值を銅めっき被膜の幅 $(5$ $\mathrm{mm})$ で除した值を平均ピール強度とした。

\subsection{4 剥離界面観察 (SEM)}

剥離界面の場所を特定するため, 走査型電子顕微鏡 （JSM-5500，日本電子社製）を用いて，ピール強度試験後 のPPS 基板表面を観察した。このときの加速電圧は， $5 \mathrm{kV}$ に設定した。

\section{3. 結果と考察}

\section{1 水滴接触角}

Table 2 に, PPS 基板の各処理前後の水滴接触角を示す。 比較として, スライドガラスの各処理前後の水滴接触角も 示している。

未処理の PPS 基板とスライドガラスの水滴接触角は，そ れぞれ $86.8^{\circ}$ と $4.5^{\circ}$ であり，材質により接触角が大きく異な ることがわかる。酸素プラズマ処理後, PPS 基板とスライ ドガラスの水滴接触角は, それぞれ $3.4^{\circ}$ と $3.2^{\circ}$ であり, 酸 素プラズマ処理により基板表面が十分に親水化されている ことがわかる。また，材質による接触角の差がなくなって いることがわかる。

PUCS 化学吸着単分子膜を被覆したPPS 基板とスライド ガラスの水滴接触角は, それぞれ $71.3^{\circ}$ と $70.9^{\circ}$ であり, PUCS 吸着前後で接触角が大幅に増加している。この值は, PUCS の吸着が行われた文献 ${ }^{18)}$ の接触角と一致しており, 文献と同様のPUCS 化学吸着単分子膜を形成していること がわかる。

ポリピロール膜を製膜したPPS 基板とスライドガラスの 水滴接触角は，それぞれ $59.8^{\circ}$ と $60.8^{\circ}$ であり，重合前後で 接触角が減少している。この值は, 酸化重合によりポリピ ロール膜が作製された文献 ${ }^{18)}$ の接触角とほぼ同值であり, PUCS 化学吸着単分子膜上にポリピロール膜が作製されて いることがわかる。

実際に, ポリピロール膜の固定状態を確認するため, 透 明粘着テープ（ $\operatorname{Scotch}^{\circledR} \mathrm{BK}-12$ ，住友スリーエム社製）をポ リピロール膜に接着させては剥離する操作を 10 回繰り返し

Table 2. Change of water contact angle (WCA) on the PPS substrate and slide glass

\begin{tabular}{l|c|c}
\hline \multicolumn{1}{c|}{$\begin{array}{c}\text { Sample preparation } \\
\text { condition }\end{array}$} & $\begin{array}{c}\text { Resin WCA } \\
{[\mathrm{deg}]}\end{array}$ & $\begin{array}{c}\text { Glass WCA } \\
{[\mathrm{deg}]}\end{array}$ \\
\hline Untreated substrate & 86.8 & 4.5 \\
\hline After the oxygen plasma treatment & 3.4 & 3.2 \\
\hline After the preparation of PUCS-CAM & 71.3 & 70.9 \\
\hline After the preparation of the polypyrrole film & 59.8 & 60.8 \\
\hline After the tape delamination test & 60.0 & 60.3 \\
\hline
\end{tabular}


Table 3. Comparison of water contact angle (WCA) on the slide glass before and after the tape delamination test

\begin{tabular}{c|c|c}
\hline \multicolumn{1}{c|}{ Sample preparation condition } & $\begin{array}{c}\text { WCA [deg] (slide } \\
\text { glass uncovered } \\
\text { with PUCS-CAM) }\end{array}$ & $\begin{array}{c}\text { WCA [deg] (slide } \\
\text { glass covered } \\
\text { with PUCS-CAM) }\end{array}$ \\
\hline $\begin{array}{c}\text { Before the tape delamination test (After the } \\
\text { preparation of the polypyrrole film) }\end{array}$ & 55.4 & 60.8 \\
\hline After the tape delamination test & 21.5 & 60.3 \\
\hline
\end{tabular}

た ${ }^{6)}$ 。テープ剥離テスト後の PPS 基板とスライドガラスの 水滴接触角は $60.0^{\circ}$ と $60.3^{\circ}$ であり, テープ剥離試験前後で 水滴接触角はほとんど変化していない。このことから，ポ リピロール薄膜が基板に強固に固定されていることがわか る。

比較実験として, PUCS 化学吸着単分子膜を被覆せず, ポリピロール膜のみを製膜したスライドガラスに対して， 同様のテープ剥離試験を行った。Table 3 にPUCS 化学吸着 単分子膜の有無を比較したスライドガラスの水滴接触角を 示す。PUCS 化学吸着単分子膜を被覆しない場合, テープ 剥離試験前の水滴接触角は $55.4^{\circ}$ であるが，テープ剥離試 験後の水滴接触角は $21.5^{\circ}$ であり, テープ剥離試験前後で 接触角が大きく減少している。一方, PUCS 化学吸着単分 子膜を被覆した場合, テープ剥離試験前後で水滴接触角は ほとんど変化していない。これらの結果から，PUCS化学 吸着単分子膜がなければポリピロール膜を基板に固定でき ないことは明らかである。

\section{2 断面 SEM写真}

Fig. 4(a) は, PUCS 化学吸着単分子膜とポリピロール膜を 製膜後, 無電解銅めっきを行い, 最後に電気銅めっきを 行ったPPS 基板の断面 SEM 写真である。Fig. 4(b) は, 比較 サンプルとして，フッ酸緩衝液(BHF)により PPS 樹脂基板 の表面粗さを増加させた後に無電解銅めっきを行い，最後 に電気銅めっきを行ったPPS 基板の断面 SEM 写真である。 Fig. 4(b) では，樹脂と銅めっき被膜との界面があれている。 一方，Fig. 4(a)では，樹脂と銅めっき被膜との界面があれ ていない。この結果は，酸素プラズマ処理，PUCS化学吸 着単分子膜の製膜, そしてポリピロール膜の製膜を行って む, マイクロオーダーで基板表面があれないことを示して いる。

\section{3 ピール強度試験}

Fig. 5 に，ピール強度試験結果を示す。それぞれのサン プルは，以下のプロセスで作製した（詳細はTable 1参照）。 Sample A は, 銅めっき前に酸素プラズマ処理のみを行った サンプルである。Sample B は，銅めっき前にPUCS 化学吸 着単分子膜のみを製膜したサンプルである。 Sample C は, PUCS 化学吸着単分子膜を製膜後, さらにピロール塩化鉄 酸化剂溶液に浸漬して酸化重合を行ったサンプルである。 Sample D は, PUCS 化学吸着単分子膜を製膜後, ピロール

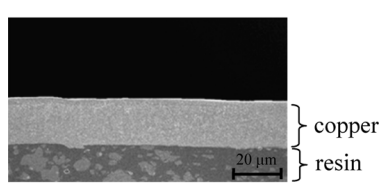

(a)

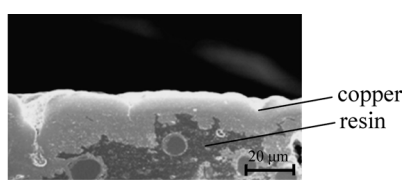

(b)
Fig. 4 Cross-sectional SEM images of the copper plated resin substrate. (a) Non-etching, (b) etching by BHF

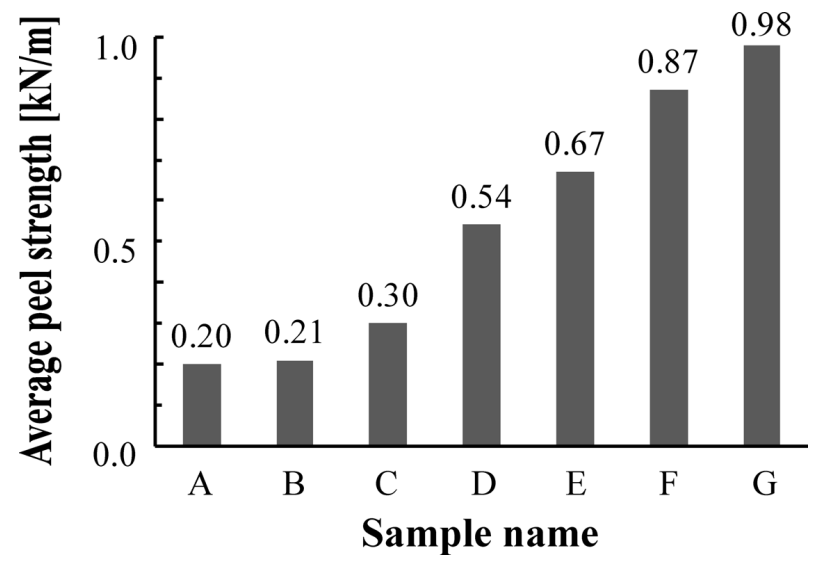

Fig. 5 Adhesion strength measured by peel strength test, indicating that adhesion strength changes with the processing

溶液に浸漬し，その後に塩化鉄酸化剂溶液に浸漬して酸化 重合を行ったサンプルである。 Sample E は, PUCS 化学吸 着単分子膜を製膜後, ピロール溶液に浸漬し，その後に塩 化鉄酸化剤溶液に浸漬し，さらにもう一度ピロール溶液に 浸漬したサンプルである。Sample F は, PUCS 化学吸着単 分子膜を製膜後，ピロール溶液に浸漬し，その後に塩化鉄 酸化剂溶液に浸漬し，さらにもう一度ずつピロール溶液と 塩化鉄酸化剂溶液に浸漬したサンプルである。Sample G は， Sample F と同じ工程であるが，酸化剤を塩化鉄から塩 化パラジウムに変更したサンプルである。

Fig. 5 に示すように，平均ピール強度（接着力）は，プ ロセスに依存することがわかる。Sample A と Sample Bを 比較すると，接着力はほとんど増加していない。このこと から, PUCS 化学吸着単分子膜のみでは, 接着力向上の効 果がないことがわかる。 Sample B と Sample Cを比較する と，接着力が約 $0.10 \mathrm{kN} / \mathrm{m}$ 向上している。このことから， PUCS 化学吸着単分子膜を製膜後, 酸化重合を行い, PUCS 化学吸着単分子膜上にポリピロール膜を製膜することは, 接着力向上に効果があることがわかる。 Sample C と Sample $\mathrm{E}$ を比較すると，接着力が約 $0.40 \mathrm{kN} / \mathrm{m}$ 向上している。この ことから，重合工程の違いにより，接着力が変化すること がわかる。Sample F と Sample G を比較すると，さらに接 着力が向上し，接着力 $0.98 \mathrm{kN} / \mathrm{m}$ を示している。この值は, 目標值 $0.60 \mathrm{kN} / \mathrm{m}$ をはるかに超える值である。このことか ら，塩化パラジウムは，塩化鉄よりも，重合工程における 


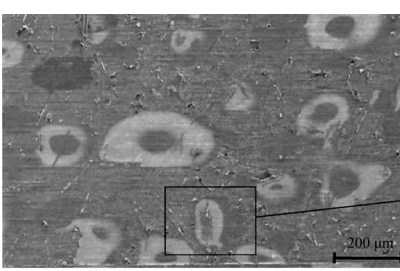

(a)

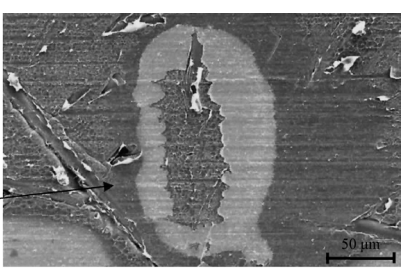

(b)
Fig. 6 SEM images of the surface of the resin substrate after the peel strength test. (a) $\times 100,(b) \times 500$.

酸化剂に適していることがわかる。

\subsection{SEM 写真}

Fig. 6 に，ピール強度試験後の PPS 基板表面 (Sample G) のSEM写真を示す。Fig. 6(a)では, ドーナツ状の模様が多 く観察できる。ドーナツ状の模様部分を拡大した Fig. 6(b) より，ピール強度試験中に樹脂が破壊されたことがわかる。 この写真より, 大部分の剥離は, 銅めっき被膜と樹脂基板 との間で起こっている（凝集破壊している）が，一部ドー ナツ状に樹脂材料が破壊されながら剥離している（基材破 壊している）ことがわかる。

\section{4. 結 論}

酸素プラズマ処理前後の水滴接触角の変化から, 酸素プ ラズマ処理によりサンプル表面の水酸基が増え, 基板表面 が親水性になったことを確認した。そして，PUCS 吸着前 後の水滴接触角の変化から, PPS 基板上にPUCS 化学吸着 単分子膜が製膜されたことを確認した。さらに, PUCS 化 学吸着単分子膜上でのピロールの酸化重合前後の水滴接触 角の変化から，ポリピロール膜が製膜されたことを確認し た。また, テープ剥離試験により, PUCS 化学吸着単分子 膜がポリピロール膜を固定していることも確認した。

ピール強度試験結果から, PUCS 化学吸着単分子膜のみ では接着力向上効果がないが，ポリピロール膜を PUCS 化 学吸着単分子膜上に製膜することで，接着力が飛躍的に向 上することがわかった。また，重合を促進させるための酸 化剂を塩化鉄 $\mathrm{Fe}(\mathrm{III}) \mathrm{Cl}_{3}$ から塩化パラジウム $\mathrm{Pd}(\mathrm{IV}) \mathrm{Cl}_{4}$ に変え ることで，さらに接着力を向上できることがわかった。そ して，目標值 $0.60 \mathrm{kN} / \mathrm{m}$ を大きく上回る接着力が得られた。 ピール強度試験後の PPS 基板表面の SEM写真から, 凝 集破壊と基材破壊の両方が起こっていることを確認でき, 樹脂材料を変更しない限り，これ以上接着力を向上できな いことがわかった。

PUCS 化学吸着単分子膜とポリピロール膜により銅イオ ンを固定した以前の研究6) と今回の結果より, PUCS 化学吸 着単分子膜内のピロリル基と追加モノマーとして添加した ピロールが重合し，ピロール系化学吸着単分子膜を介して， 基板と結合したポリピロール膜が形成されたため接着力が 向上したと推測できる。すなわち，Fig. 7 に示すように，

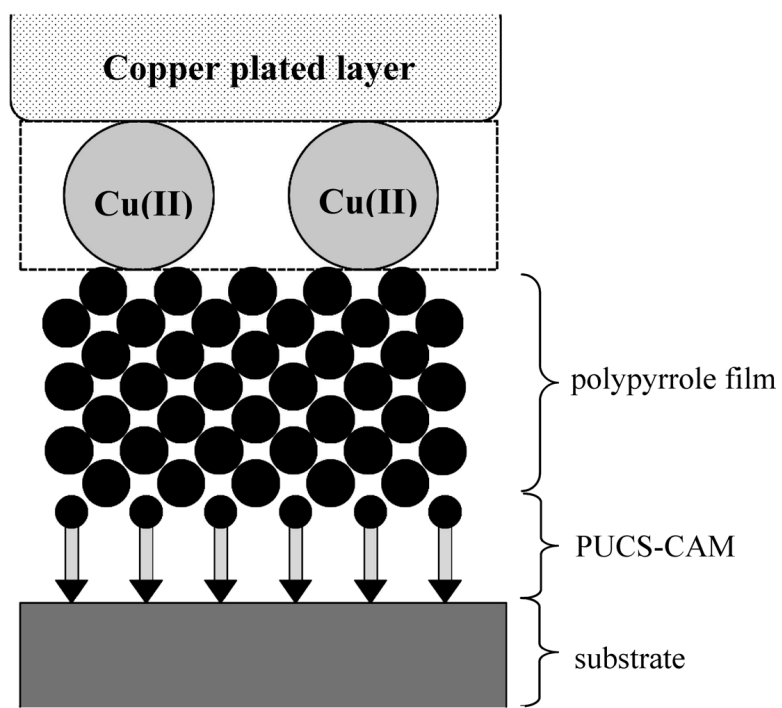

Fig. 7 Schematic diagram of the mechanism for the adhesion improvement by PUCS-CAM and the polypyrrole thin film

PPS 基板と銅めっき被膜は, PUCS 化学吸着単分子膜とポ リピロール膜を介して，共有結合，配位結合，金属結合で 結合しているため，高い接着力を示したと考えられる。

なお，本技術は，樹脂基板の表面粗さを増加することな く, 銅めっき被膜の接着力を大幅に向上できるため, 各種 電子部品の製造において大いに役に立つであろう。

\section{謝 辞}

本研究を進めるにあたって，研究測定装置の貸与および 実験材料を提供していただいたアルプス電気社の宮澤聡研 究員，副島和博研究員に，深く感謝いたします。そして， 実験全体を通して多大なご協力およびご助言を頂いたアル プス電気社の仲野陽研究員に厚く御礼申し上げます。

(2010.7.6-受理)

\section{文献}

1）高木 清：“プリント配線板における表面処理の動向,”表 面技術，Vol. 59, No. 9, pp. 570-577, 2008年9月

2) 榎本英彦，村田俊也：“プラスチック上へのめっきの現状 之将来,”表面技術, Vol. 59, No. 5, pp. 282-287, 2008 年5月

3) 榎本英彦, 中村 恒 (編) : “電子部品のめっき技術, ” pp. 145-154，日刊工業新聞社，2002 年

4) 梅原弘次，小早川紘一，佐藤祐一：“液晶ポリマーへの無 電解銅めっき,”マイクロエレクトロニクスシンポジウム論 文集，Vol. 12, pp. 363-366, 2002年10月

5) 斎藤 囲, 本間英夫，山下嗣人，小岩一郎 (編)：“入門新 めっき技術”，pp. 252-262，工業調査会，2007年

6) 大久保雄司, 大西正悟, 小川一文: “ピロール系化学吸着 単分子膜を介したポリピロール薄膜による銅イオンの固 定,”表面技術，Vol. 60, No. 12, pp. 805-810, 2009年 12 月 
7) 曽我真守, 小川一文, 尾崎伸司, 増田泰士, 後藤邦夫 : “フッ化アルキルトリクロロシランによるガラス基板のはっ 水処理,”表面科学, Vol. 14, No. 10, pp. 630-635, 1993年 12 月

8) R. A. Simon, A. J. Ricco, and M. S. Wrighton: "Synthesis and Characterization of a New Surface Derivatizing Reagent to Promote the Adhesion of Polypyrrole Films to $N$-type Silicon Photoanodes: N-(3-(Trimethoxysilyl)propyl) Pyrrole," J. Am. Chem. Soc., Vol. 104, No. 7, pp. 2031-2034, April 1982

9) C.-G. Wu and C.-Y. Chen: "Chemical Deposition of Ordered Conducting Polypyrrole Films on Modified Inorganic Substrates," J. Mater. Chem., Vol. 7, No. 8, pp. 1409-1413, August 1997

10) D. Cossement, F. Plumier, J. Delhalle, L. Hevesi, and Z. Mekhalif: "Electrochemical Deposition of Polypyrrole Films on Organosilane-modified ITO Substrates," Synthetic Metals, Vol. 138, No. 3, pp. 529-536, July 2003

11) K. Ogawa, N. Mino, and S. Yamamoto: "Formation of Electric Paths in a Chemically Adsorbed Monomolecular Layer Containing Pyrrolyl Groups," Thin Solid Film, Vol. 468, No. 1-2, pp. 240-243, December 2004

12) S. Yamamoto and K. Ogawa: "The Electrical Conduction of
Conjugated Molecular CAMs Studied by a Conductive Atomic Force Microscopy," Surface Science, Vol. 600, No. 18, pp. 4294-4300, September 2006

13）福元達也，小川一文：“ケミカルチップ流路への適用を目 指した表面エネルギー制御による通過液体の流速制御, ”表 面技術，Vol. 59, No. 1, pp. 57-62, 2008年1月

14) A. Malinausksa: "Chemical Deposition of Conducting Polymers," Polymer, Vol. 42, No. 9, pp. 3957-3972, April 2001

15) M. Can, H. Ozaslan, and O. Isldak: "Investigation of Catalytic Effects of the Proton and Lewis Acids on Oligomerization and Chemical Polymerization of Pyrrole," Polymer, Vol. 45, No. 20, pp. 7011-7016, September 2004

16) 辻一誠，大久保雄司，小川一文：“化学吸着技術を用い て作製した超撥水・撥油表面の研究，”表面技術，Vol. 59, No. 7, pp. 38-42, 2008年 7 月

17） JISハンドブックシリーズ “金属表面処理,”H8630，日本規 格協会, 1998年, pp. 272-273

18) C.-G. Wu, S.-C. Chiang, and C.-H. Wu: "Formation and Electrochemical Property of Pyrrole-Terminated SAMs and the Effect of the SAMs on the Physicochemical Properties of Polypyrrole Films Electrochemically Deposited over Them," Langmuir, Vol. 18, No. 20, pp. 7473-7481, April 2002 